\title{
Ways Forward for Advancing Ecosystem Services in Municipal Planning-Experiences from Stockholm County
}

\author{
Sara Khoshkar ${ }^{1, *(\mathbb{D}, \text { Monica Hammer }}{ }^{2}$, Sara Borgström ${ }^{1}\left[\right.$ and Berit Balfors $^{1}$ \\ 1 Department of Sustainable Development, Environmental Science and Engineering, \\ KTH Royal Institute of Technology, 10044 Stockholm, Sweden; sara.borgstrom@abe.kth.se (S.B.); \\ balfors@kth.se (B.B.) \\ 2 School of Natural Sciences, Technology and Environmental Studies, Södertörn University, \\ 14189 Huddinge, Sweden; monica.hammer@sh.se \\ * Correspondence: khoshkar@kth.se
}

Received: 4 August 2020; Accepted: 25 August 2020; Published: 26 August 2020

\begin{abstract}
This case study from Stockholm County, Sweden, explores practitioners' experiences of barriers and bridges in municipal planning practices to support actions for ecosystem services. This qualitative study is based on information gathered from a focus group, workshops, and semi-structured interviews, which aided in identifying key factors for integrating ecosystem services in municipal planning. We identified $10 \mathrm{key}$ factors divided into three themes: (i) regulatory framework and political support, (ii) local organizational capacity, and (iii) local adaptation of tools and practices. In particular, the practitioners pointed to the need for the development of legal support and regulations for ecosystem services on the national and EU policy levels. Furthermore, the need for local capacity building and understanding of ecosystem services as well as increased regional support to enhance local knowledge exchange and learning was emphasized. Also, in a decentralized local governance system such as in Sweden, to fully implement ecosystem services in urban planning for sustainable development, locally adapted practical tools and monitoring procedures were considered important.
\end{abstract}

Keywords: capacity building; ecosystem services; municipal planning practice; urban governance

\section{Introduction}

Globally, multiple human drivers, degrading biodiversity and ecosystem functions and services [1] have significantly altered ecosystems. To prevent further decline and restore ecosystems, there is a need for transformation and change for socioeconomic development to strengthen the delivery of ecosystem services (ES) [2]. ES are defined generally as the functions performed by nature that directly or indirectly benefit humankind and contribute to well-being (e.g., water regulation, air regulation, recreation) [1]. Agenda 2030 states that ES and biodiversity are relevant to all sustainable development goals (SDGs) and emphasizes the need for action [3].

Urban areas are rapidly growing in Europe, for example, Berlin, Malaga, and Stockholm [4]. The increasing number and expansion of urban areas underline the importance of integrating ES in spatial planning [5,6]. Strategic decisions on land use allocations made during the planning process can have significant impacts on urban green spaces and their capacity to support the provision of ES. The integration of ES into urban planning processes is considered to provide a more comprehensive understanding of the values at stake and of the synergies and trade-offs that might arise from land-use decisions [7]. 
Although the knowledge and awareness of the relevance of ES has increased, there remains a gap in the mainstreaming and implementation of ES in practical planning and decision-making [8,9].

Spatial planning in Europe varies amongst the different countries, influenced by the governance arrangements and institutional settings [10,11]. In Sweden, municipalities have the main responsibility for spatial planning [12] and local management practices play a key role in sustaining urban ES [13]. Decisions that consider ES at the local planning level can enhance the provision of biodiversity and ES and generate benefits that occur at multiple levels from local to global [14,15]. Also, affiliated planning instruments like strategic environmental assessment (SEA) have been recognized as opportunities to enhance decision-making by including the ES approach [16,17].

The importance of governance systems that have the potential to safeguard the long-term delivery and use of ES at different levels of governance is emphasized [6]. Different challenges confronted when implementing ES into practical governance have been identified in the literature related to awareness and interest among practitioners, coordination between planning departments, as well as processes and routines $[18,19]$. In a study from Berlin, based on qualitative content analysis and semi-structured interviews, several governance challenges for the implementation of ES were identified, including financial constraints, loss of expertise, and insufficient communication about benefits from urban green spaces to key decision-makers [20]. In Rotterdam, the main challenges included a lack of coordination between planning departments and a lack of evaluation of and learning from pilot projects [21]. The governance challenges for the implementation of ES can be different depending on the countries' governance arrangements. However, current ES approaches often do not take existing governance structures and practices as a starting point, and tend to focus on issues such as the spatial extent of ES [22]. Hence, to assimilate the ES framework in urban planning practice rather than in single projects, it is important to gain an understanding of the governance context including institutional frameworks, existing policies, and planning systems [23]. Furthermore, the views of practitioners and decision-makers involved in the planning process are important for the implementation of ES, particularly on the potentials and added value of using the concept and what tools could be used in practical integration [24]. In light of the transition towards decentralized governance in many European countries [25] and the uniquely strong position of Swedish municipalities in planning [26], the Stockholm case provides an interesting context to examine and contribute to the knowledge on ES implementation in local planning practice.

In our study, drawing on empirical experiences of practitioners in Swedish municipal planning, we explored and analyzed local spatial planning practices to identify key factors for advancing ES implementation in planning processes focusing on municipalities in Stockholm County as a case study. The following research questions formed the basis of this paper:

i. What were the practitioner's experiences and views on challenges and needs for integrating ecosystem services in municipal planning practice?

ii. What key factors could be identified for supporting the integration of ecosystem services in municipal planning practices?

\section{Theoretical Framework}

\section{Urban Governance and Spatial Planning}

Governance can be defined as the institutions, structures, and processes that determine who make decisions, how and for whom decisions are made, whether, how, and what actions are taken and by whom [27]. In urban regions, spatial planning is a key component of governance efforts to guide development processes [28]. To achieve changes for planning [29] emphasizes that the use of knowledge is a central element. More specifically, [30] highlights the role of expert knowledge in order to take planning and development systematically in directions for contributing to the achievement of defined goals. The authors emphasize that it is important to note that various forms of knowledge interplay in planning processes, with actors from different sectors and levels involved. Therefore, even with the 
existence of the relevant expert knowledge, it may be overruled by the knowledge of actors involved. In the context of planning for ES, new knowledge about ES does not necessarily influence decisions, because complex interactions within and across governance systems may have implications for the actual implementation in policies and plans [31,32]. [33] also discuss that environmental knowledge alone does not shift priorities from unsustainable practices to sustainable development since priority setting is influenced by competing interests and political agendas, power relations and modes of governance, regulatory frameworks, and property rights.

Furthermore, multiple governmental and non-governmental actors and institutions are involved in planning for ecosystem services and decision-making, which can lead a heterogeneity of practices dependent on the governance context [34]. This involves that the management of ecosystems and landscapes requires an integration of various sources of information and knowledge from various levels and sectors of society [22,35]. Moreover, coordination between involved actors is required to create coherent action and strengthen the role of ES in spatial planning. However, changing land-use patterns, diverse interests, and values of actors on different scales poses challenges for the governance and planning of ES when negotiating the trade-offs in the provision of such ES [36,37].

Lastly, many methods, approaches, and tools have been tested to support decision-making in applying the ES concept [38]. Actions and tools are said to constitute the core of a plan [39], and the probability of success of an action depends on the type of tools used [40]. However, [41] emphasizing that tools and methods alone are not enough to support ES, there remains a need to encourage better ES management. For example, there is a need to provide access to the tools and foster their use through knowledge exchange and application in practice [38-42].

Overall, as highlighted by [43] more attention should be given on how to facilitate change that moves the concept of ES from an "ideal into reality". According to [31], empirical evidence is needed on the governance of ecosystem services, including issues of decision-making and policy implementation. Our paper contributes to the above research gap by providing insight on practices and experiences of ES implementation from a decentralized governance setting and presenting key factors for advancing ES in planning practice.

\section{Swedish Governance Context}

In Sweden, ES was introduced in the 2010 Swedish Environmental Policy (Government Bill 2009/10:155) and was further elaborated in 2012 [44]. More specifically, two milestone targets related to the implementation of ES were added in 2012 [44]. Furthermore, in 2013, the Swedish government assigned an inquiry (SOU:2013:68) to analyze actions and propose methods and measures to better evaluate ES and integrate the importance of biodiversity and the value of ES into economic plans and other decisions in society [45]. As a result, the ES concept has been implemented to varying degrees in the different parts and at different levels of Swedish society. In 2018, two additional targets regarding ES were added which called for municipalities to (i) have access to a developed method for utilizing and integrating urban greenery and ecosystem services in urban environments, in planning, construction and management by 2020, and (ii) shall utilize and integrate urban greenery and ecosystem services in urban environments in planning, construction and management by 2025 [46]. Hence, at a national level, there is a strong political will to implement ES approaches as a strategy for urban sustainable development in Sweden.

The local level of governance, consisting of 290 municipalities, has an important role in meeting the sustainability targets related to ES. More specifically, the municipalities hold a planning monopoly, where regional and national authorities can intervene when national regulations are at risk of being violated [47]. Spatial planning in Sweden is regulated through the Planning and Building Act (PBA) (National Board of Housing, Building, and Planning) and the Environmental Code (Swedish Environmental Protection Agency) (SEPA) [48]. The PBA mainly regulates exploitation, while the Environmental Code mainly addresses the conservation/protection of land or water [49]. Municipal comprehensive plans (MCP) and detailed development (local) plans are the main statutory 
planning instruments in Swedish spatial planning [50]. In accordance with the PBA, municipalities have an important role in coordinating their comprehensive plans with plans and policies at other levels of government and demonstrating how the international, national, regional, and local goals will be met. A recent analysis of the integration of ES in the MCPs revealed that these plans are increasingly addressing concrete strategies or measures for the provision and/or conservation of ES [51].

\section{Materials and Methods}

\subsection{Case Study Area}

The geographic scope for this study was set as Stockholm County, which is Sweden's largest urbanized region, consisting of 26 municipalities [52]. The planning practices and challenges presented in this study are gathered from six municipalities within Stockholm County: Huddinge, Haninge, Nacka, Stockholm, Täby, and Upplands Väsby (Figure 1). The selection of municipalities represents a mix of rapidly growing urban and peri-urban areas with extensive ongoing urban densification. Moreover, these municipalities have initiated different activities to strengthen ES in their planning practice by, for example, developing approaches and tools for ES mapping, applying for external funding for ES projects, and developing ES strategies. Table 1 provides a brief description of the municipalities studied including population size, projected population size by 2030, percentage of population growth between 2018 and 2030, population density, total land area, and percentage of developed land.

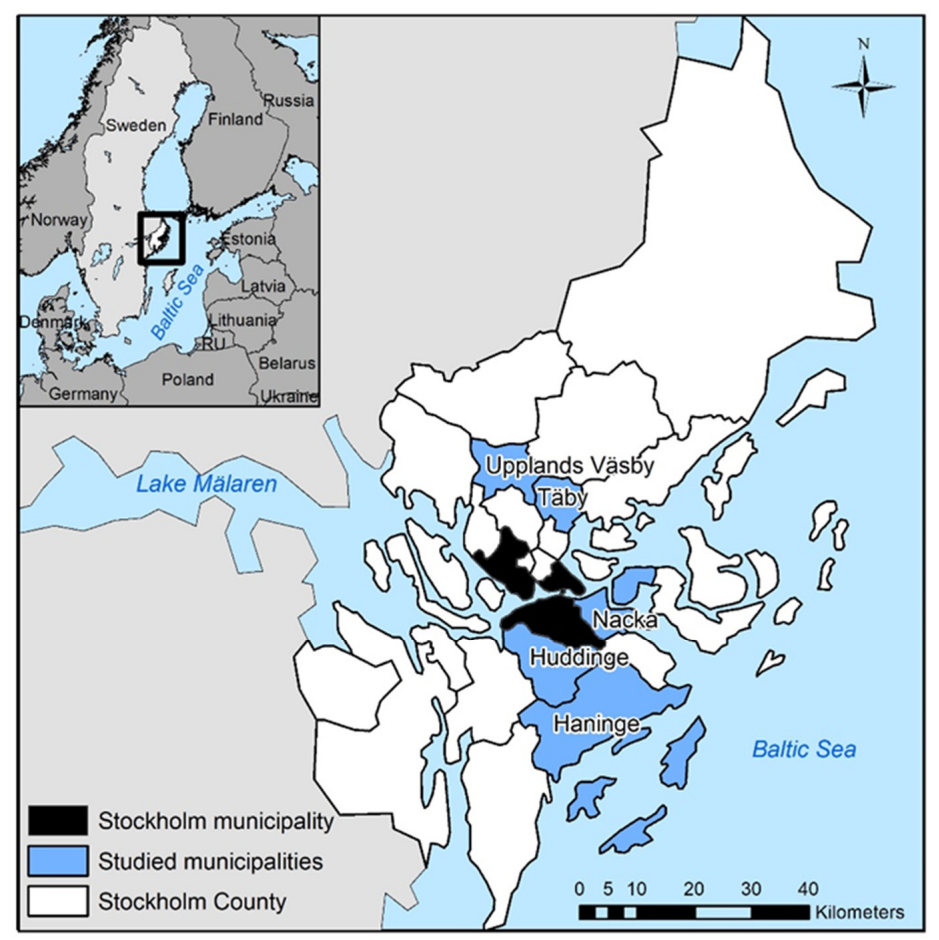

Figure 1. Map of Sweden, zoomed to Stockholm County and municipalities comprised in the study.

Table 1. Overview of municipality statistics (Source: Region Stockholm, 2019; SCB, 2019).

\begin{tabular}{|c|c|c|c|c|c|c|}
\hline Municipality & $\begin{array}{l}\text { Population } \\
\text { Size (2018) }\end{array}$ & $\begin{array}{c}\text { Projected } \\
\text { Population Size by } \\
2030\end{array}$ & $\begin{array}{c}\% \text { of Population } \\
\text { Growth } \\
(2018-2030)\end{array}$ & $\begin{array}{l}\text { Population Density } \\
\text { (Inhabitants } / \mathrm{km}^{2} \text { ) }\end{array}$ & $\begin{array}{l}\text { Total Land Area } \\
\left(\mathrm{km}^{2}\right)(2015)\end{array}$ & $\begin{array}{l}\text { Built-up Land } \\
\text { (\%) (2015) }\end{array}$ \\
\hline Haninge & 89,989 & 121,160 & 35 & 42 & 455 & 12 \\
\hline Huddinge & 111,722 & 145,698 & 30 & 790 & 131 & 28 \\
\hline Nacka & 103,656 & 119,205 & 15 & 800 & 94 & 37 \\
\hline
\end{tabular}


Table 1. Cont.

\begin{tabular}{|c|c|c|c|c|c|c|}
\hline Municipality & $\begin{array}{l}\text { Population } \\
\text { Size (2018) }\end{array}$ & $\begin{array}{c}\text { Projected } \\
\text { Population Size by } \\
2030\end{array}$ & $\begin{array}{c}\% \text { of Population } \\
\text { Growth } \\
(2018-2030)\end{array}$ & $\begin{array}{l}\text { Population Density } \\
\text { (Inhabitants } / \mathrm{km}^{2} \text { ) }\end{array}$ & $\begin{array}{l}\text { Total Land Area } \\
\left(\mathrm{km}^{2}\right)(2015)\end{array}$ & $\begin{array}{l}\text { Built-up Land } \\
(\%)(2015)\end{array}$ \\
\hline Stockholm & 962,154 & $1,050,660$ & 9 & 5200 & 187 & 55 \\
\hline Täby & 71,397 & 81,783 & 14 & 1000 & 60 & 36 \\
\hline Upplands Väsby & 45,543 & 58,374 & 28 & 2653 & 75 & 18 \\
\hline
\end{tabular}

\subsection{Research Design}

The empirical basis of the paper is a qualitative research study, including a mixed set of methods: one focus group, three workshops, and five semi-structured interviews between June 2018 and September 2019. Gathering data and information through different methods provides divergent perspectives, which according to [53] creates a more complex understanding of the phenomena studied. The study began with a focus group, which allowed for in-depth exploration and discussion on ES practice in spatial planning, and aided in the development of the discussions for the workshops in accordance with [54]. With support from the theoretical framework, themes for improved ES practices were derived and refined through an iterative process based on the information and discussions in the focus group, workshops and semi-structured interviews. Throughout the research process, at least two researchers documented discussions as written notes, which were compiled and cross-checked.

\subsection{Focus Group Discussion}

An exploratory focus group discussion was organized in accordance with [54] with three experienced municipal practitioners from three municipalities in June 2018, with the aim to discuss future directions for ES in municipal planning. The size of focus groups can vary, however, according to [55], a group size of between 3 and 5 is easy to manage and provides opportunities for all participants to discuss and share views and experiences. The participants were selected based on purposeful sampling, which is a strategy in which particular settings, persons or activities are selected deliberately to provide information that is of relevance to the research questions [56]. The selected participants were three of the most experienced municipal practitioners working with ES in their respective municipalities. More specifically, in their respective municipalities, they had experience of working closely with several research projects regarding ES implementation, as well as in other municipalities and governance levels from which they shared their experiences. The discussions were centered on two questions formulated by the research team: (i) what are the lessons and experiences of ES implementation from ongoing or completed urban development projects? (ii) What are the future directions for ES in municipal planning practice? The outcome of the focus group provided a basis for the topics of discussion for the following workshops, as well as insight into the municipal practitioner's experiences of working with ES.

\subsection{Workshops}

Based on the discussion in the focus group, a sequence of three half-day workshops were organized on three separate occasions (April, May, and June 2019), discussing the same topic and involving different participant constellations. Workshops were chosen to gather information because they provide the opportunity to elicit rich information from participants selected through purposeful sampling [57]. Furthermore, workshops provide the opportunity for stakeholders of different organizations to collaborate with one another and share experiences [58]. The participants of the workshops included representatives from local and regional governance, construction sector, consultants, and academia (Table 2). In general, the same participants did not participate in more than one workshop. The mixed group of participants allowed for the gathering of different perspectives and views. The discussions in the sequence of workshops focused on factors to advance ES practice in municipal planning, along with challenges that may hinder the implementation. 
Table 2. The constellation of participants attending the workshops in April, May, and June 2019.

\begin{tabular}{ccc}
\hline Workshop & Number of Participants & Constellation of Participants \\
\hline April 2019 & 16 & $\begin{array}{c}\text { Municipal practitioners, environmental consultants, construction } \\
\text { sector, academia. }\end{array}$ \\
\hline May 2019 & 30 & $\begin{array}{c}\text { Municipal practitioners, environmental consultants, construction sector, } \\
\text { Stockholm County Administrative Board (SCAB), National Board of Housing, } \\
\text { Building and Planning, Swedish Environmental Protection Agency, } \\
\text { municipal politicians, } \\
\text { academia }\end{array}$ \\
\hline June 2019 & 18 & $\begin{array}{c}\text { Municipal practitioners, environmental consultants, construction sector, } \\
\text { Stockholm County Administrative Board (SCAB), National Board of Housing, } \\
\text { Building and Planning, Swedish Environmental Protection Agency, } \\
\text { municipal politicians, } \\
\text { academia }\end{array}$ \\
\hline
\end{tabular}

\subsection{Semi-structured Interviews}

Following the focus group and workshops, five semi-structured interviews (60-90 min) between July and September 2019 were conducted with selected municipal practitioners to validate the researcher's understanding of the gathered information. Prior to the interviews, an interview guide was developed following [59], which summarized the challenges, needs, and key factors identified in the preceding research settings. Identified key factors for advancing ES in planning practice were presented to the participants, providing them the opportunity to elaborate on the researcher's findings. The interviewees were selected based on their involvement in the focus group and workshops, as well as their leading role in working with activities involving ES in the respective municipalities.

\subsection{Thematic Analysis}

A thematic analysis in accordance with [54] was conducted based on the theoretical framework and the views and experiences gathered from the focus group, workshops, and interviews. Three main themes were identified: (i) regulatory framework and political support (ii) organizational capacity building for implementation of ES in municipal planning (iii) tools and practices for ES in the local context. The themes were refined through an iterative process in relation to the workshop and interview series. For each of the themes, challenges, and needs were identified. Next, key factors for strengthening ES implementation were linked to the challenges and needs within the three themes.

\section{Results}

Below, the identified key factors for implementing ES in local planning in relation to the practitioner's experiences and views are discussed according to the three themes (see also Table 3). In most cases, general patterns are presented rather than individual viewpoints of the different participants.

\subsection{Regulatory Framework and Political Support}

Within the Swedish context, the planning of ES is regulated through both the Planning and Building Act (PBA) and the Environmental Code. According to many participants in our study, ES is still regarded as an aesthetic question, rather than a technical requirement in the legislation. More specifically, the participants pointed out that in accordance with the legislation, the detailed development plans can control what actions cannot be taken, but the possibility of placing stronger demands on developers to conduct specific actions is limited, including implementation of measures to enhance ES. The limitations of PBA regarding ecosystem services are also highlighted by [60], who argue that, in contrast to, for example, parking spaces, there are a lack of clear standards related to the size and number of blue-green space, which places them at risk in land use decision making processes. The participants emphasized that the need arises to develop voluntary municipal policies related to ES in urban development projects in order to provide targets and measures for the inclusion 
of ES in planning and decision-making. One practitioner highlighted the importance of integrating knowledge from green space plans into the comprehensive plans because then there is a "possibility to really push ecosystem services into the comprehensive plans". Furthermore, in the municipality of Huddinge, ES has been incorporated into the municipality's overarching goals to become a sustainable municipality by 2030. One goal identified was "balanced ecosystem services" (see also [61]), including several sub-goals related to ES (e.g., reduced climate impact, water), which the municipality was working towards. Aligning ES work with existing regulations and municipal organizational goals has been suggested to be important for motivating the integration of ES thinking [62]. The participants also emphasized that to support ES in local policy, there is a need to strengthen the integration of ES in EU policies and regulations. The importance of EU legislation was emphasized by exemplifying how different issues become more or less prioritized due to how they are framed in a juridical sense. For example, in the studied municipalities, regulating ES related to water quality tends to have stronger support in the legislation because of binding instruments at higher governance levels, such as the EU Water Framework Directive (2000/60/EC), with clear indicators and requirements that all EU member states must achieve in relation to ecological and chemical water quality.

Even though there is a strong national political support to integrate ES into societal decision-making including urban planning processes, the political support at the local municipal level was identified as a key factor for advancing the implementation of ES. Political shifts were described as directly influencing the available resources, as well as prioritizations among planning objectives and approaches. According to the participants in our study, the benefits of working with ES to achieve national and regional visions must be conveyed to the politicians. More specifically, a participant stated that, "decision-makers are on board when you can translate nature into their conceptions (e.g., storm water, economic benefits)." Hence, communicating the ES concept to local decision-makers was another key factor identified. In Stockholm County, a network of eight southern municipalities in the central urban region employed a development coordinator tasked with communicating within and across municipalities, as well as with municipal decision-making bodies (e.g., local politicians, municipal CEOs). More concretely, in one of the workshops, a local politician suggested using more scenarios to illustrate and serve as a communication tool with the potential to gain interest among politicians.

\subsection{Organizational Capacity Building for Implementing ES in Municipal Planning}

In a decentralized planning system like in Sweden, local capacity building is important. There is a need for local knowledge to maneuver confronted challenges in the specific local contexts. According to the participants, an important success factor is the internal basic knowledge of ES. Furthermore, the level of integration of ES in the detailed development plans could vary depending on the basic knowledge of ES of the persons involved in the planning process. Consequently, it was suggested that when the ES knowledge base is lacking, it becomes important to build capacity and learn from others. There is also a need for the knowledge to be maintained and developed within the municipal organization and their daily practices. One format to facilitate knowledge exchange and learning discussed was the development of meeting platforms where municipal practitioners could share their experiences and examples of working with ES. One such national platform exists regarding climate change adaptation in Sweden (Swedish Portal for Climate Change Adaptation). Also, the new online guidance on ES in urban planning, developed by the National Board of Housing, Building, and Planning has ambitions to provide such a platform [63]. Furthermore, the Swedish Environmental Protection Agency (SEPA) has also developed a guide on how to value ES, with step-by-step directions and examples [64]. However, the practitioners discussed that for those municipalities that have already started developing their own routines for integrating ES into planning, these guidance documents were developed too late to provide the needed support. They expressed a need of advisory support for keeping and extending the use of ES within the planning practice, as well as with capacity building within the organization. More specifically, the practitioners emphasized the importance of strengthening the advisory role on the regional level where the County Administrative Board (CAB), is tasked with 
reviewing the detailed development plans before an application for a construction permit is submitted. According to the practitioners, a limited number of ES are amongst the criteria that are checked in the review process. For example, ES connected to water quality is checked, which has led to water issues gaining momentum and more resources being allocated to studies for handling storm water and flooding within the municipalities. As emphasized by the practitioners, if legislation is strengthened to enable the regulation of a full range of ES in the detailed development plans, the advisory role of the $\mathrm{CAB}$ could have the potential of ensuring the implementation of actions related to ES.

Additionally, within municipal organizations, there is a frequent change of employees, also confirmed by [65]. This could present challenges, especially if key personnel leading ES initiatives leave a project, process, or the organization. The next person to take over the position may or may not have the same level of knowledge, experience, or motivation to continue with the previous initiatives. Thus, developing processes and routines for transferring knowledge efficiently and institutionalizing ES knowledge and procedures within municipal organizations is a key factor. Also, the development of systematic monitoring plans with relevant indicators can aid in identifying if ES was integrated in the planning process and actually resulted in implementation as well as contributing to capacity building. Examples provided by the practitioners from the case study municipalities included the municipality of Huddinge, which since 2017, has an annual follow up of their 89 environmental goals in order to monitor the status of implemented actions, initiated measures, delayed actions, and goal completion. The conservation of green areas and biodiversity are amongst these goals. In the municipality of Täby, a practitioner shared the experience of how to structure a follow-up phase. This has been "incorporated into the planning process, which takes place after the adoption of the detailed development plan, and before submission of an application for a construction permit." The follow-up aims to ensure that the quality level of the planned development follows in accordance with what had been agreed by the municipality and developers during the planning process.

\subsection{Tools and Practices for ES Implementation in the Local Context}

In Sweden, the 290 municipalities differ in land use, population, and financial resources affecting the possibilities of implementation of ES in local planning. When working with ES in local municipal planning, the need for incorporating ES into municipal routines was discussed by the participants, with many emphasizing the need to find established ways of working, evaluating practice in the different departments, identifying any gaps and who should fill those gaps. The participants pointed out that several of the progressive municipalities in the Stockholm region have developed their own planning instruments on a voluntary basis as a complement to required municipal comprehensive plans, in order to support planning processes that recognize specific issues such as ES. One example is Upplands Väsby municipality, that has developed extensive planning instruments on ES including "Mapping of Ecosystem Services" and "Development Plan for Ecosystem Services". More recently, the municipality has developed an action plan to support the implementation of the established strategies for ES in municipal activities. Parallel to the voluntary instruments, the participants emphasized the importance of driven individuals to lead the learning process on how to use these planning instruments within the organization for successful implementation.

Also, the participants highlighted the importance of specific roles and clear responsibilities for implementing the ES approach. The planning process was described as being long and extensive and the individuals involved in setting the strategic vision are often not involved in the implementation phase. Consequently, the vision set at the start regarding specific ES (e.g., tree planting) may not be implemented. As one of the participants stated, "when developing the detailed development plan in particular, there should be at least one person involved with the competence of ES." However, depending on the resources available in the municipalities, this is not always the case. Furthermore, the material concerning ES was described as being extensive but fragmented. There is an overall lack of clarity regarding who should be responsible for consolidating ES at the municipal level and there are different approaches by different municipalities, which also impact how it is implemented [66]. 
In the studied municipalities, two potential tools for ES in the planning of new developments were highlighted, Point System 2.0 and the green space factor (GSF). Point System 2.0 was an adaptation of the original Point System to include ES and was developed in Upplands Väsby. The GSF has been implemented in several of the municipalities in Stockholm County. The aim of the Point System is to facilitate collaboration and encourage construction companies to work with sustainability measures at an early stage. Through the application of this tool, the developers will receive points for implementing sustainability measures, which, in turn, generate discounts on the price of the land. In Upplands Väsby, a points system was applied to a large-scale project, Fyrklövern, which has been described as the largest residential building project in the municipality in 30 years, involving 14 different construction companies (see also [67]). As a basis for the points system, a series of dialogue meetings with the citizens and different actors involved in the planning and development process were organized to identify novel ideas for the new development project. The experiences gained from the implementation of the points system were being used to develop an updated version, which includes measures for ES. According to the practitioner, this version has the potential to be a "tool for discussion to keep the ES alive, providing more room to discuss what we want in a particular place". The GSF is a tool for increasing green spaces within development projects while minimizing the extent of sealed or paved surface designs that have been applied in many cities around the world (e.g., Malmö, Seattle, Berlin) [68,69]. In Stockholm, it has also been used in several of the municipalities and was appreciated by the practitioners as a way to facilitate dialogue between municipalities and the developers. GSF enabled concrete measures to increase the proportion of greenery on the land that had been set for development.

As a means of building capacity in terms of internal learning and establishing routines, Haninge municipality organized an educational workshop about GSF for the different departments to enhance the usage in detailed development planning processes.

Furthermore, the experience from Upplands Väsby was that "maps to identify ES were the starting point to bring ES into the planning process and permitted knowledge to be gained on what exists, what is needed and what means exist for fulfilling the needs." However, a question was raised regarding how long these maps would be relevant and the need to continuously update them was emphasized, although there was often a lack of resources to do so.

Table 3. Summary of challenges and key factors for strengthening ES implementation.

\begin{tabular}{|c|c|c|}
\hline Themes & Challenges and Needs & Keys Factors for Strengthening ES Implementation \\
\hline $\begin{array}{l}\text { Regulatory framework and } \\
\text { political support }\end{array}$ & $\begin{array}{c}\text { ES still regarded as an aesthetic question, rather than } \\
\text { a technical requirement in legislation } \\
\text { Lack of clear standards related to size and number of } \\
\text { blue/green space, placing them at risk in land-use } \\
\text { decision-making processes } \\
\text { Lack of political support }\end{array}$ & $\begin{array}{l}\text { Strengthen EU policies and regulations } \\
\text { National legislation and regulations } \\
\text { Communication and local support }\end{array}$ \\
\hline $\begin{array}{l}\text { Organizational capacity building for } \\
\text { implementation of ES in } \\
\text { municipal planning }\end{array}$ & $\begin{array}{l}\text { Different levels of knowledge of ES in the } \\
\text { municipal organization } \\
\text { Frequent change of employees in the municipalities } \\
\text { Need for structured monitoring and learning } \\
\text { from experiences }\end{array}$ & $\begin{array}{c}\text { Increase local knowledge on ES } \\
\text { Platforms (local and regional) for knowledge } \\
\text { exchange and learning } \\
\text { Strengthen support and advisory role of the regional } \\
\text { (county level) } \\
\text { Develop routines for monitoring and evaluation of } \\
\text { ES in the planning process }\end{array}$ \\
\hline $\begin{array}{l}\text { Tools and practices for ES } \\
\text { implementation in the local context }\end{array}$ & $\begin{array}{l}\text { Long and extensive planning process with different } \\
\text { expertise involvedLack of clear roles and } \\
\text { responsibilitiesNeed for tailored tools and routines to } \\
\text { implement ES in local development projects }\end{array}$ & $\begin{array}{l}\text { Develop action plans on how to implement } \\
\text { ES strategies } \\
\text { Established individual roles and responsibilities } \\
\text { Develop, test and adapt existing tools including } \\
\text { maps/GIS, point systems to the local context }\end{array}$ \\
\hline
\end{tabular}

\section{Discussion}

Our study explored and analyzed practitioner's views and experiences of local spatial planning practices in municipalities in Stockholm County in order to identify key factors for supporting the integration of ES in municipal planning practice. We found a heterogeneity of practices and experiences amongst municipalities studied. This is expected in light of the strong local planning monopoly and the responsibility of each individual municipality to derive strategies and measures to reach the national and regional goals. Consequently, it may lead to the consideration of relevant goals for ES to be applied 
differently across municipalities [49]. Also, the diverse development patterns within the municipalities put forth different prerequisites and challenges that each municipality must work with [51]. Similarly, it has been observed in European countries, that the differences in methods, policy mandates and funding mechanisms for ES implementation, results in heterogeneous practices and needs [70].

As discussed in the preceding sections, urban governance systems have the potential to facilitate the use of ES at different levels of governance [6]. However, many factors can influence the uptake of ES, such as political priorities, available knowledge base, and the municipal arrangements [30-34]. In the Swedish local planning context, we identified 10 key factors divided into three themes for supporting the integration of ES in the municipal planning practice (See Table 3). The factors are linked to the identified challenges and needs based on the practitioner's views and experiences.

Our findings indicate that regulatory frameworks that set mandatory requirements for a range of ES are important for supporting the implementation of ES in local planning practice. This is in line with [33] emphasis on the importance of integrating ES into EU level regulatory frameworks such as the Thematic Strategy on the Urban Environment and other regulatory frameworks that guide spatial planning and natural resource management. Also, [71] argues that the management of biodiversity has binding instruments, for example, the Habitat Directive (92/43/EEC) for specific species and non-binding instruments such as the Biodiversity Strategy 2020, but there remains a need for a specific EU policy devoted to governing urban ES. In line with supporting EU regulation, as a legally required instrument, Strategic Environmental Assessment has been identified to be a good entry point for integrating ES in spatial planning, as it is already established as a widespread (often mandatory) process to assess effects of policies, programs and plans [6,72]. For example, the SEA of spatial plans can ensure that ES is taken into account when evaluating different planning alternatives [73]. Furthermore, although the municipalities have a local planning monopoly, political support and resources are necessary in order to enable local initiatives to be implemented, such as local municipal action plans for ES or the development of new tools. Therefore, communication with local decision-makers is important, also emphasized by [74], who suggest that the values of ES should be communicated to decision-makers in a transparent and viable way. A development coordinator, similar to the example provided in the eight southern municipalities in Stockholm County, can facilitate communication between the municipalities and local politicians.

Furthermore, developing and maintaining the knowledge base related to ES in municipal organizations and their daily practices is needed to strengthen the implementation of ES. This is especially important with the frequent transition of employees in municipal organizations. A study of ES planning in Australia [75] highlighted that the turnover of government staff combined with factors such as weak regulatory support resulted in stagnation in the development and adoption of ES policies and practices. Measures for organizational capacity building can aid in confronting the challenges associated with the changing knowledge bases. For example, the development of meeting platforms between municipalities can provide a means for knowledge exchange amongst the practitioners working with ES. Also, clearly established roles and responsibilities can aid in maintaining the ES knowledge throughout a long and extensive planning process. Previous studies have also highlighted the importance of individuals who take an active role in promoting the ES approach in municipal organizations $[33,62]$. Additionally, our findings indicate the important role of regional authorities $(\mathrm{CAB})$ to enhance local knowledge exchange and learning.

Adapting existing tools to different contexts and challenges faced is also important for supporting the implementation of ES as emphasized by the practitioners. In Berlin, a governance challenge identified when implementing ES was how to address certain groups of stakeholders (e.g., private property owners), which have the ability to implement strategic goals [20].

In this context, existing tools such as the points system implemented in Upplands Väsby or the green space factor can be adopted and adapted to enable dialogue with the groups of stakeholders. In the Swedish context, these tools aided in facilitating dialogue with the developers to work with sustainability issues in the development projects. Furthermore, the points system invited the local 
community to contribute to ideas. However, it is important to have an understanding of the limits of the planning tools. For example, a risk that may occur with the use of tools such as the Green Space Factor at the local project scale is the possibility to lose the overall regional perspective on green infrastructure.

A common finding in previous studies is the need for structured monitoring and learning from experiences [20,21]. Developing routines for monitoring and evaluation of ES in the planning process following the examples of Täby and Huddinge can provide a way forward for strengthening monitoring and facilitating learning. However, it is important to note that incorporating follow-up procedures in the planning process also requires the process to be evaluated in order to learn from the experiences [76]. According to [74], data and information regarding ecosystem services and the impact of development on them should continuously be gathered and integrated with the goal of learning, adapting and better-informing policy. Overall, our study was directed towards practitioners in the municipalities due to their active role and responsibility for implementing ES in their daily practice. Examining the views and experiences of the practitioners involved in the planning and decision making processes for implementing ES in the local planning context allowed us to gain insight on the bridges and barriers for operationalizing ES. However, future studies directed towards citizens and local actor's perceptions of ES could further contribute to the understanding of challenges for ES implementation by practitioners.

\section{Conclusions}

The case study from Stockholm County provided wide empirical material and experiences of practitioners working under different municipal arrangements in a rapidly growing urban region. Consequently, the findings of this paper can contribute to better understand the factors that can facilitate the integration of ES in local planning practice. Four main conclusions can be drawn from this study. Firstly, there is a need for legal support and regulations for ES on the national and EU policy level. Secondly, local political support is necessary to enable the municipalities to take initiatives. Therefore, there is a need for communication between the municipal practitioners and local politicians so to foster learning concerning ES implementation. Thirdly, knowledge related to ecosystem services and motivation amongst the municipal actors is a key factor for implementing ecosystem services in the municipal planning practice. Capacity building initiatives are necessary within the municipalities to maintain and develop the ES knowledge in the municipal organization. Fourthly, monitoring is important in order to ensure that the visions set strategically are translated into concrete actions and to learn from experiences. Overall, advancing ES in local planning requires a combination of top-down political support and bottom-up planning initiatives from local actors.

Author Contributions: Conceptualization, S.K.; methodology, S.K.; writing-original draft preparation, S.K.; writing-review and editing, M.H., S.B. and B.B.; supervision, B.B. and M.H.; funding acquisition, B.B. All authors have read and agreed to the published version of the manuscript.

Funding: This research was funded by FORMAS Research Council, grant number 2015-00133.

Acknowledgments: We thank Mona Petersson for help with the layout of the map.

Conflicts of Interest: The authors declare no conflict of interest. The funders had no role in the design of the study; in the collection, analyses, or interpretation of data; in the writing of the manuscript, or in the decision to publish the results.

\section{References}

1. Reid, W.V.; Mooney, H.A.; Cropper, A.; Capistrano, D. Ecosystems and Human Well-Being: Synthesis. A Report of Millenium Ecosystem Assessment; Island Press: Washington, DC, USA, 2005.

2. IPBES. IPBES Global Assessment on Biodiversity and Ecosystem Services. Second order draft; IPBES: Bonn, Germany, 2018.

3. United Nations. Transforming Our World_The 2030 Agenda for Sustainable Development; United Nations: New York, NY, USA, 2015. 
4. Eurostat. Urban Europe-Statistics on Cities, Towns and Suburbs; Publications office of the European Union: Luxembourg, 2016.

5. Geneletti, D.; Cortinovis, C.; Zardo, L.; Esmail, B.A. Planning for Ecosystem Services in Cities; Springer: Cham, Switzerland, 2019.

6. Ronchi, S. Ecosystem Services for Spatial Planning-Innovative Approaches and Challenges for Practical Applications; Springer: Cham, Switzerland, 2018.

7. De Groot, R.; Alkemade, R.; Braat, L.; Hein, L.; Willemen, L. Challenges in integrating the concept of ecosystem services and values in landscape planning, management and decision making. Ecol. Complex. 2010, 7, 260-272. [CrossRef]

8. Albert, C.; Aronson, J.; Fürst, C.; Opdam, P. Integrating ecosystem services in landscape planning: Requirements, approaches, and impacts. Landsc. Ecol. 2014, 29, 1277-1285. [CrossRef]

9. Lautenbach, S.; Mupepele, A.-C.; Dormann, C.F.; Lee, H.; Schmidt, S.; Scholte, S.S.K.; Seppelt, R.; Van Teeffelen, A.J.A.; Verhagen, W.; Volk, M. Blind spots in ecosystem services research and challenges for implementation. Reg. Environ. Chang. 2019, 19, 2151-2172. [CrossRef]

10. Davoudi, S.; Evans, E.; Governa, F.; Santangel, M. Territorial governance in the making. Approaches, methodologies, practices. Bol. Asoc. Geogr. Esp. 2008, 46, 33-52.

11. Oliveira, E.; Hersperger, A.M. Disentangling the governance configurations of strategic spatial plan-making in European urban regions. Plan. Pr. Res. 2018, 34, 47-61. [CrossRef]

12. Högström, J.; Balfors, B.; Hammer, M. Planning for sustainability in expansive metropolitan regions: Exploring practices and planners' expectations in Stockholm, Sweden. Eur. Plan. Stud. 2017, 26, 439-457. [CrossRef]

13. Andersson, E.; Barthel, S.; Borgström, S.; Colding, J.; Elmqvist, T.; Folke, C.; Gren, Å. Reconnecting cities to the biosphere: Stewardship of green infrastructure and urban ecosystem services. Ambio 2014, 43, 445-453. [CrossRef]

14. Fisher, B.; Turner, R.K.; Morling, P. Defining and classifying ecosystem services for decision making. Ecol. Econ. 2009, 68, 643-653. [CrossRef]

15. Farley, J.; Costanza, R. Payments for ecosystem services: From local to global. Ecol. Econ. 2010, 69, $2060-2068$. [CrossRef]

16. Geneletti, D. A Conceptual Approach to Promote the Integration of Ecosystem Services in Strategic Environmental Assessment. J. Environ. Assess. Policy Manag. 2015, 17. [CrossRef]

17. Mascarenhas, A.; Ramos, T.B.; Haase, D.; Santos, R. Ecosystem services in spatial planning and strategic environmental assessment-A European and Portuguese profile. Land Use Policy 2015, 48, 158-169. [CrossRef]

18. Mann, C.; Loft, L.; Hansjürgens, B. Governance of ecosystem services: Lessons learned for sustainable institutions. Ecosyst. Serv. 2015, 16, 275-281. [CrossRef]

19. Galler, C.; Albert, C.; Von Haaren, C. From regional environmental planning to implementation: Paths and challenges of integrating ecosystem services. Ecosyst. Serv. 2016, 18, 118-129. [CrossRef]

20. Kabisch, N. Ecosystem service implementation and governance challenges in urban green space planning-The case of Berlin, Germany. Land Use Policy 2015, 42, 557-567. [CrossRef]

21. Haase, D.; Frantzeskaki, N.; Elmqvist, T. Ecosystem services in urban landscapes: Practical applications and governance implications. Ambio 2014, 43, 407-412. [CrossRef] [PubMed]

22. Primmer, E.; Furman, E. Operationalising ecosystem service approaches for governance: Do measuring, mapping and valuing integrate sector-specific knowledge systems? Ecosyst. Serv. 2012, 1, 85-92. [CrossRef]

23. Opdam, P.; Albert, C.; Fürst, C.; Grêt-Regamey, A.; Kleemann, J.; Parker, D.; La Rosa, D.; Schmidt, K.; Villamor, G.B.; Walz, A. Ecosystem services for connecting actors-Lessons from a symposium. Chang. Adapt. Socio Ecol. Syst. 2015, 2, 1-7. [CrossRef]

24. La Rosa, D. Why is the inclusion of the ecosystem services concept in urban planning so limited? A knowledge implementation and impact analysis of the Italian urban plans. Socio Ecol. Pr. Res. 2019, 1, 83-91. [CrossRef]

25. Nadin, V.; Maldonado, A.M.F.; Zonneveld, W.; Stead, D.; Dabrowski, M.; Piskorek, K.; Sarkar, A.; Schmitt, P. COMPASS-Comparative Analysis of Territorial Governance and Spatial Planning Systems in Europe: Applied Research 2016-2018: Final Report; ESPON \& TU Delft: Luxembourg, 2018.

26. Johnson, G. Regional planning in Sweden. In Planning and Sustainable Urban Development in Sweden; Lundström, M.J., Fredriksson, C., Witzell, J., Eds.; Swedish Society for Town \& County Planning: Stockholm, Sweden, 2013. 
27. Bennett, N.; Satterfield, T. Environmental governance: A practical framework to guide design, evaluation, and analysis. J. Soc. Conserv. Biol. 2018, 11, e12600. [CrossRef]

28. Albrechts, L.; Healey, P.; Kunzmann, K.R. Strategic Spatial Planning and Regional Governance in Europe. J. Am. Plan. Assoc. 2003, 69, 113-129. [CrossRef]

29. Rydin, Y. Re-examining the role of knowledge within planning theory. Plan. Theory 2007, 6, 52-68. [CrossRef]

30. Tennøy, A.; Hansson, L.; Lissandrello, E.; Næss, P. How planners' use and non-use of expert knowledge affect the goal achievement potential of plans: Experiences from strategic land-use and transport planning processes in three Scandinavian cities. Prog. Plan. 2016, 109, 1-32. [CrossRef]

31. Primmer, E.; Jokinen, P.; Blicharska, M.; Barton, D.N.; Bugter, R.; Potschin, M. Governance of ecosystem services: A framework for empirical analysis. Ecosyst. Serv. 2015, 16, 158-166. [CrossRef]

32. Ratamäki, O.; Jokinen, P.; Sørensen, P.B.; Breeze, T.; Potts, S. A multilevel analysis on pollination-related policies. Ecosyst. Serv. 2015, 14, 133-143. [CrossRef]

33. Saarikoski, H.; Primmer, E.; Saarela, S.-R.; Antunes, P.; Aszalós, R.; Baró, F.; Berry, P.; Blanko, G.G.; Goméz-Baggethun, E.; Carvalho, L.; et al. Institutional challenges in putting ecosystem service knowledge in practice. Ecosyst. Serv. 2018, 29, 579-598. [CrossRef]

34. Buijs, A.; Elands, B.; Havik, G.; Ambrose-Oji, B.; Gerőházi, E.; van der Jagt, A.; Mattijssen, T.; Møller, M.S.; Vierikko, K. Innovative Governance of Urban Green Spaces: Learning from 18 Innovative Examples across Europe; EU FP7 GREEN SURGE Project; Department of Geosciences and Natural Resource Management, University of Copenhagen: Copenhagen, Denmark, 2016.

35. Folke, C.; Hahn, T.; Olsson, P.; Norberg, J. Adaptive governance of social-ecological systems. Annu. Rev. Environ. Resour. 2005, 30, 441-473. [CrossRef]

36. Loft, L.; Mann, C.; Hansjürgens, B. Challenges in ecosystem services governance: Multi-levels, multi-actors, multi-rationalities. Ecosyst. Serv. 2015, 16, 150-157. [CrossRef]

37. Hammer, M.; Bonow, M.; Petersson, M. The role of horse keeping in transforming peri-urban landscapes: A case study from metropolitan Stockholm, Sweden. Nor. J. Geogr. 2017, 71, 146-158. [CrossRef]

38. Patenaude, G.; Lautenbach, S.; Paterson, J.S.; Locatelli, T.; Dormann, C.F.; Metzger, M.J.; Walz, A. Breaking the ecosystem services glass ceiling: Realising impact. Reg. Environ. Chang. 2019, 19, 2261-2274. [CrossRef]

39. Brody, S.D.; Highfield, W.; Carrasco, V. Measuring the collective planning capabilities of local jurisdictions to manage ecological systems in southern Florida. Landsc. Urban Plan. 2004, 69, 33-50. [CrossRef]

40. Cortinovis, C.; Geneletti, D. Ecosystem services in urban plans: What is there, and what is still needed for better decisions. Land Use Policy 2018, 70, 298-312. [CrossRef]

41. Rounsevell, M.D.A.; Metzger, M.J.; Walz, A. Operationalising ecosystem services in Europe. Reg. Environ. Chang. 2019, 19, 2143-2149. [CrossRef]

42. Schoonover, H.A.; Grêt-Regamey, A.; Metzger, M.J.; Ruiz-Frau, A.; Santos-Reis, M.; Scholte, S.S.K.; Walz, A.; Nicholas, K.A. Creating space, aligning motivations, and building trust: A practical framework for stakeholder engagement based on experience in 12 ecosystem services case studies. Ecol. Soc. 2019, 24, 11. [CrossRef]

43. Braat, L.C.; De Groot, R. The ecosystem services agenda:bridging the worlds of natural science and economics, conservation and development, and public and private policy. Ecosyst. Serv. 2012, 1, 4-15. [CrossRef]

44. Ministry of Environment. Swedish Environmental Objectives-Clarification of Environmental Quality Objectives and a First Set of Targets; Ds 2012:23; Ministry of the Environment: Stockholm, Sweden, 2012.

45. Ministry of Environment. Making the Value of Ecosystem Services Visible; SOU 2013:68; Ministry of Environment: Stockholm, Sweden, 2013.

46. SEPA. Fördjupad Utvärdering av Miljömålen 2019; Swedish Environment Protection Agency: Stockholm, Sweden, 2019.

47. Hedström, R.T.; Lundström, M.T. Swedish Land-use Planning Legislation. In Planning and Sustainable Urban Development in Sweden; Lundström, M.J., Fredriksson, C., Witzell, J., Eds.; Swedish Society for Town \& County Planning: Stockholm, Sweden, 2013.

48. Persson, C. Deliberation or doctrine? Land use and spatial planning for sustainable development in Sweden. Land Use Policy 2013, 34, 301-313. [CrossRef]

49. Lidmo, J.; Bogason, Á.; Turunen, E. The Legal Framework and National Policies for Urban Greenery and Green Values in Urban Areas-A Study of Legislation and Policy Documents in the Five Nordic Countries and Two European Outlooks; Nordregio Report 2020:3; Nordregio: Stockholm, Sweden, 2020. 
50. Koglin, T.; Pettersson, F. Changes, problems, and challenges in Swedish spatial planning-An analysis of power dynamics. Sustainability 2017, 9, 1836. [CrossRef]

51. Khoshkar, S.; Hammer, M.; Borgström, S.; Dinnétz, P.; Balfors, B. Moving from vision to action-integrating ecosystem services in the Swedish local planning context. Land Use Policy 2020, 97, 104791. [CrossRef]

52. SCC. Regional Utvecklingsplan fo"r Stockholmsregionen. RUFS 2050. Europas Mest Attraktiva Storstadsregion; Stockholm County Council, SCC: Stockholm, Sweden, 2018.

53. Greene, J.C. Mixed Methods in Social Inquiry; Jossey-Bass: San Francisco, CA, USA, 2007.

54. Bryman, A. Social Research Methods, 2nd ed.; Oxford University Press: New York, NY, USA, 2012.

55. Peek, L.; Fothergill, A. Using focus groups: Lessons from studying daycare centers, 9/11, and Hurricane Katrina. Qual. Res. 2009, 9, 31-59. [CrossRef]

56. Palys, T.; Given, L. Purposive Sampling. In The SAGE Encyclopedia of Qualitative Research Methods; Sage Publications: Thousand Oaks, CA, USA, 2008; p. 698.

57. Creswell, J.W. Research Design. Qualitative, Quantitative and Mixed Methods Approaches; Sage: Thousand Oaks, CA, USA, 2014.

58. Ørngreen, R.; Levinsen, K. Workshops as a research methodology. Electr. J. e-Learn. 2017, 15, 70-81.

59. Kvale, S.; Brinkmann, S. Interviews, Learning the Craft of Qualitative Research Interviewing; Sage: Thousand Oaks, CA, USA, 2009.

60. Wihlborg, M.; Sörensen, J.; Olsson, J.A. Assessment of barriers and drivers for implementation of blue-green solutions in Swedish municipalities. J. Environ. Manag. 2019, 233, 706-718. [CrossRef]

61. Huddinge Municipality. Environment Barometer. 2019. Available online: http://miljobarometern.huddinge. se/ (accessed on 1 October 2019).

62. Blicharska, M.; Hilding-Rydevik, T. “A thousand flowers are flowering just now"-Towards integration of the ecosystem services concept into decision making. Ecosyst. Serv. 2018, 30, 181-191. [CrossRef]

63. National Board of Housing, Building and Planning. Ecosystem Services in the Built Environment. 2019. Available online: https://www.boverket.se/sv/PBL-kunskapsbanken/Allmant-om-PBL/teman/ ekosystemtjanster/ (accessed on 1 October 2019).

64. Swedish Environmental Protection Agency. Guide for Valuing Ecosystem Services; Rapport 6690; Swedish Environmental Protection Agency: Stockholm, Sweden, 2015.

65. Jakobsson, A.; Kofoed Schröder, J.; Balfors, B. Tools and Working Methods for Managing Ecosystem Services in Detailed Planning; Report TRITA-ABE-RPT-202; KTH Royal Institute of Technology: Stockholm, Sweden, 2020; ISBN 978-91-7873-538-9. (In Swedish)

66. Borgström, S. Appendix 4: Ecosystem Services perspective in Swedish Environmental policy and practice, potentials, barriers and ways for integration. In SOU 2013:68 Synliggöra Värdet av Ekosystemtjänster. Åtgärder för Välfärd Genom Biologisk Mångfald Och Ekosystemtjänster; Regeringen: Stockholm, Sweden, 2013; pp. 245-258.

67. Upplands Väsby. The Point System. 2019. Available online: http://upplandsvasby.se/minisajter/fyrklovern/ om-fyrklovern/poangsystemet.html (accessed on 2 October 2019).

68. Kruuse, A. The green space factor and green points system. Town Country Plan. J. 2011, 80, 287-290.

69. Juhola, S. Planning for a green city: The Green Factor tool. Urban For. Urban Green. 2018, 34, $254-258$. [CrossRef]

70. Schröter, M.; Albert, C.; Marques, A.; Tobon, W.; Lavorel, S.; Maes, J.; Brown, C.; Klotz, S.; Bonn, A. National ecosystem assessments in europe: A review. BioScience 2016, 66, 813-828. [CrossRef] [PubMed]

71. Bouwma, I.; Schleyer, C.; Primmer, E.; Winkler, K.J.; Berry, P.; Young, J.; Carmen, E.; Špulerová, J.; Bezák, P.; Preda, E.; et al. Adoption of the ecosystem services concept in EU policies. Ecosyst. Serv. 2018, 29, $213-222$. [CrossRef]

72. Helming, K.; Diehl, K.; Geneletti, D.; Wiggering, H. Mainstreaming ecosystem services in European policy impact assessment. Environ. Impact Assess. Rev. 2013, 40, 82-87. [CrossRef]

73. Slootweg, R. Ecosystem services in SEA: Are we missing the point of a simple concept? Impact Assess. Proj. Apprais. 2015, 34, 1-8. [CrossRef]

74. Costanza, R.; De Groot, R.; Braat, L.; Kubiszewski, I.; Kubiszewski, I.; Sutton, P.C.; Farber, S.; Grasso, M. Twenty years of ecosystem services: How far have we come and how far do we still need to go? Ecosyst. Serv. 2017, 28, 1-16. [CrossRef] 
75. Keenan, R.J.; Pozza, G.; Fitzsimons, J.A. Ecosystem services in environmental policy: Barriers and opportunities for increased adoption. Ecosyst. Serv. 2019, 38, 100943. [CrossRef]

76. Gustafsson, S.; Andréen, V. Local Spatial Planning Processes and Integration of Sustainability Perspective Through a Broad Systems Perspective and Systematic Approach; Springer: Cham, Switzerland, 2017; pp. 567-580.

(C) 2020 by the authors. Licensee MDPI, Basel, Switzerland. This article is an open access article distributed under the terms and conditions of the Creative Commons Attribution (CC BY) license (http://creativecommons.org/licenses/by/4.0/). 